\title{
PENGARUH ELECTRONIC WORD OF MOUTH DAN POTONGAN HARGA TERHADAP PEMBELIAN IMPULSIF PRODUK SKINCARE
}

\author{
Triana Ariska Wulandari \\ Universitas Singaperbangsa Karawang \\ 1810631020043@student.unsika.ac.id \\ Muhamad Ikhsanul Insan \\ Universitas Singaperbangsa Karawang \\ 1810631020131@student.unsika.ac.id \\ Ajat Sudrajat \\ Universitas Singaperbangsa Karawang \\ ajat.sudrajat@fe.unsika.ac.id
}

\begin{abstract}
One of the business fields in the field of secondary/tertiary needs that is growing quite rapidly in Indonesia and the city of Karawang, to be precise, is the business in cosmetics. One of the cosmetic fields that are experiencing improvement is skincare. One of the marketing techniques that companies use to attract consumers is Electronic Word Of Mouth or eWOM. In addition, the factor of price discounts can also greatly influence the purchase decision of a product by potential customers and correlates with eWOM, as in e-commerce in Indonesia which always provides discount programs on specific dates. The purpose of this research is to determine whether there is a positive effect of eWOM and Discount on impulsive purchase of skincare products. The method used in this research is the quantitative research method. The data analysis process used the IBM SPSS 21 Software, which processed the data using primary data sources and a questionnaire as the instrument. The interpretation is that there is a positive influence given by two variables independent, namely Electronic Word of Mouth and Discount, on the impulsive buying process of mediheal skincare sheet masks partially and simultaneously.
\end{abstract}

Keywords: discounts; eWOM; impulsive purchases; sheetmask; skincare.

\section{PENDAHULUAN}

Salah satu bisnis di bidang kebutuhan sekunder/tersier yang sedang berkembang cukup pesat di Indonesia adalah bisnis kosmetik. Pasar kecantikan dan perawatan diri (kosmetik) di Indonesia mencapai US \$6.03 milliar tahun 2019, dan akan tumbuh menjadi US\$ 8,46 milliar tahun 2022. Industri produk kecantikan berpotensi akan terus tumbuh (euromonitor, 2020).

Banyak faktor yang menjadi penentu evaluasi konsumen akan produk skincare. Evaluasi konsumen juga bergantung kepada bagaimana suatu perusahaan bisa menarik konsumen dengan teknik marketing yang tepat. Teknik marketing yang banyak dilakukan pemasar berupaya memunculkan pembelian impulsif. Pembelian impulsif merupakan suatu kegiatan di mana di dalamnya terdapat proses untuk terjadinya pembelian yang tidak diniatkan sebelumnya (Rook, 1987).

Salah satu teknik marketing yang bisa dilakukan perusahaan untuk menarik para konsumen adalah Electronic Word of Mouth atau eWOM. eWOM merupakan pendapat dan atau penialaian terhadap suatu produk untuk ditampilkan kepada calon konsumen yang berpotensi melalui media (Yulianton, 2017). Hal ini mengacu pada kenyataan di lapangan dan data statistik di Indonesia bahwa per-tahun 2019 nilai kapitalisasi e-commerce, mencapai angka USD $\$ 21$ milliar bahkan diprediksi akan terus meningkat sampai dengan angka USD\$22 milliar tahun 2022 (Kemp, 2019).

eWOM merupakan salah satu teknik pemasaran yang dapat dipercaya oleh suatu perusahaan yaitu dengan cara memelihara kesan dan pesan suatu produk, di mana penilaian tersebut akan menjadi salah satu bahan pertimbangan dalam keputusan para calon konsumen untuk pada akhirnya membeli produk tersebut ataupun tidak, dan perusahaan juga dapat melakukan pengawasan serta analisis terhadap 
kesan produknya melalui media internet dengan harapan dapat mencakup golongan pasar yang tidak terbatas (Ismagilova et al., 2017).

Kotler (2015) mengemukakan potongan harga adalah suatu pengurangan harga yang diberikan perusahaan dalam periode tertentu, Hal ini juga menjadi salah satu faktor utama dan cukup kuat dalam usaha untuk memengaruhi keputusan pembelian suatu produk oleh para calon konsumen dan juga meningkatkan penjualan suatu produk. Kedua variabel tersebut memiliki dampak terhadap keputusan pembelian yang terencana dan juga memengaruhi keputusan pembelian impulsif bagi para calon konsumen.

Produk skincare sheetmask Mediheal adalah satu dari sekian banyak produk skincare yang diproduksi oleh Perseroan Terbuka (PT) L\&P Cosmetic. Mediheal merupakan merek unggul dalam industri kecantikan dan telah menjual lebih dari 100 juta produk masker sejak 2009 dengan rating yang tinggi (Soco.id, 2018).

Penelitian ini bertujuan untuk menganalisis pengaruh eWOM dan potongan harga terhadap pembelian impulsif produk kosmetik skincare.

\section{KAJIAN PUSTAKA DAN PENGEMBANGAN HIPOTESIS}

\section{Electronic Word of Mouth (eWOM)}

Weisfeld-Spolter et al. (2014) menyampaikan bahwa eWOM adalah suatu hal yang penting dalam kegiatan pemasaran dengan tujuan utama untuk mengembangkan ekspresi target pasar terhadap suatu produk atau jasa. Hasil dari cipta merek yang ditampilkan secara online memberikan informasi bahwa pembelian ditimbulkan oleh kuatnya peranan yang diberikan oleh eWOM dalam proses mengaktfikan citra merek.

Word of Mouth (WOM) adalah tindakan konsumen dalam memberi informasi penilaian tentang suatu barang, jasa, merek, atau perusahaan kepada konsumen lain. Apabila informasi tersebut dikomunikasikan melalui internet, hal tersebut disebut Electronic Word of Mouth (Rosario et al., 2016). Dimensi eWOM terdiri dari 3 bagian besar yaitu eWOM message, eWOM source, dan eWOM receiver (Ismagilova et al., 2017:52-53).

\section{Potongan Harga}

Menurut Baskara (2016), diskon atau potongan harga adalah suatu teknik promosi dan pemasaran yang di dalamnya berfungsi untuk mengurangi suatu harga produk dari harga biasanya. Menurut Tjiptono (2019:310), diskon atau potongan harga adalah suatu fasilitas yang diberikan kepada para konsumen atau para pembeli oleh suatu produsen atau suatu perusahaan atas suatu kegiatan tertentu dilaksanakan oleh pembeli, seperti contohnya adalah apabila konsumen membayar tagihan lebih cepat, apabila konsumen berbelanja dengan jumlah besar atau apabila transaksi dilakukan di luar periode permintaan paling tinggi.

Menurut Kotler (2015), diskon diberikan karena beberapa faktor, di antaranya karena akan ada model yang lebih terkini, terjadi kesulitan dalam proses penjualan, adanya kondisi masalah keuangan berbahaya yang dialami oleh suatu perusahaan, dan atau apabila menunggu terlalu lama dikhawatirkan barang-barang tersebut akan mengalami penurunan harga yang jauh lebih besar.

\section{Pembelian Impulsif}

Dalihade et.al. (2017) menjelaskan bahwa pembelian impulsif adalah suatu proses transaksi yang dilakukan terhadap suatu barang, di mana pembeli tidak mempunyai niatan awal untuk bertransaksi terhadap produk tersebut, dengan kata lain proses transaksi terjadi secara tidak direncanakan sebelumnya. Menurut Sugianto (2016), impulse buying merupakan suatu kondisi di mana ketika para pembeli merasakan keinginan yang tidak diduga sebelumnya dan sangat besar untuk membeli suatu produk pada saat yang sama, muncul karena ada suatu hal yang spesial selama berbelanja. 
Wulandari et al., Pengaruh Electronic Word of Mouth dan Potongan Harga terhadap Pembelian Impulsif Suatu Produk Skincare

\section{Hubungan antar Variabel}

Untuk meningkatkan tingkat penjualan suatu produk, diperlukan suatu strategi sales promotion, yang di mana akhirnya memiliki tujuan untuk mendorong pembelian terhadap suatu produk. Dalam meningkatkan efektifitas dari suatu sales promotion, diperlukan alat-alat yang tepat, di antaranya yaitu eWOM dan potongan harga. Kedua hal tersebut adalah variabel yang diduga dapat berpengaruh langsung terhadap perilaku pembelian impulsif para konsumen. Kusnanto et.al. (2020), Setiawan dan Putri (2020), serta Sugianto (2017) membuktikan pengaruh eWOM dan harga terhadap pembelian impulsif suatu produk. Gambar 1 menunjukkan kerangka pikir penelitian ini.

H1: Ada pengaruh secara simultan antara eWOM dan potongan harga terhadap pembelian impulsif produk kecantikan skincare sheetmask Mediheal.

eWOM telah dilihat sebagai salah satu yang penting posisi nya di dalam dunia pemasaran industri 4.0 (Ismigilova, 2017). Semua kegiatan ekonomi di masa sekarang yang sangat berkaitan erat dengan dunia teknologi membuat kebanyakan konsumen lebih berfokus dan memercayai kualitas suatu produk yang dituliskan secara daring atau review yang di mana itu sendiri merupakan salah satu bentuk dari eWOM, Teori ini dibuktikan oleh penelitian sebelumnya yang dilakukan oleh Sugianto, (2017) dan Rosario, (2017) menunjukkan pengaruh positif yang ditimbulkan eWOM terhadap pembelian impulsif.

H2: Terdapat pengaruh secara parsial eWOM terhadap pembelian impulsif produk kecantikan skincare sheetmask Mediheal.

Pembelian impulsif dipengarui oleh promosi dengan bentuk potongan harga yang diberlakukan oleh suatu usaha (Kusnanto et.al., 2020; Bayu, 2016). Kotler (2015) juga menekankan bahwa ada pengaruh besar yang ditimbulkan oleh potongan harga dalam proses pembelian impulsif suatu produk

H3: Terdapat pengaruh secara parsial potongan harga terhadap pembelian impulsif produk kecantikan skincare sheetmask Mediheal.

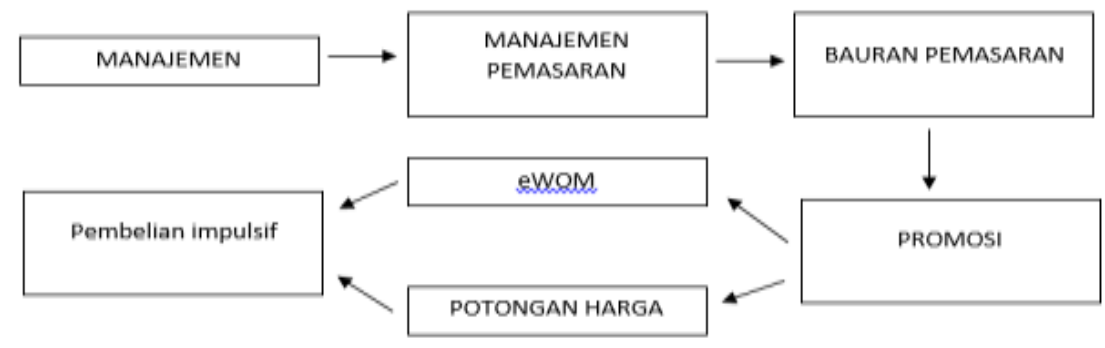

Gambar 1. KERANGKA PIKIR

\section{METODE PENELITIAN}

Metode yang digunakan pada penelitian ini yaitu metode penelitian kuantitatif. Penelitian ini dilakukan di Kota Karawang. Populasi dalam penelitian ini yaitu remaja berumur 19-24 tahun yang berdomisili di Kota Karawang dan mengenal merek Mediheal. Jumlah sampel adalah 162 sampel. Teknik pengambilan sampel adalah purposif. Survei dilakukan dengan menggunakan kuesioner dengan skala Likert. Data dianalisis dengan menggunakan regresi linier berganda dengan software SPSS. 


\section{HASIL DAN PEMBAHASAN}

\section{Karakteristik Responden}

Pada penelitian ini jumlah keseluruhan dari sampel tersebut yaitu 162 responden. Berdasarkan usia, mayoritas responden yang mengisi kuesioner penelitian ini adalah pria ataupun wanita yang pernah melakukan pembelian produk skincare mediheal dengan umur 20 tahun, berada pada angka 67 Individu atau $58.2 \%$ dari total data yang masuk. Berlanjut kepada profil responden yang dibagi berdasarkan jenis pekerjaan, mayoritas atau kebanyakan responden yang mengisi kuesioner penelitian ini adalah pria atau wanita yang di mana masih berstatus pelajar ataupun mahasiswa, dengan jumlah 107 atau 93\% dari total data yang ada. Dengan kata lain, kelompok penghasilan "0 - 1.500.000" adalah kelompok penghasilan yang paling banyak jumlahnya, yaitu 94 individu atau $81.7 \%$ dari total data yang dikumpulkan.

\section{Hasil Uji Validitas dan Hasil Uji Reliabilitas}

Pada variabel eWOM dinyatakan valid, hal ini berdasarkan keputusan bahwa apabila $r$ hitung lebih besar daripada $r$ tabel, maka kuesioner tersebut valid, di dalam uji validitas variabel ini, $r$ tabel nya adalah 0.183 dan semua $r$ hitung yang ada di data melebihi angka tersebut. Pada variabel potongan harga dinyatakan valid, hal ini berdasarkan keputusan bahwa apabila $r$ hitung lebih besar daripada $r$ tabel, maka kuesioner tersebut valid, di dalam uji validitas variabel ini, $r$ tabel nya adalah 0.183 dan semua $\mathrm{r}$ hitung yang ada di data melebihi angka tersebut. Pada variabel pembelian impulsif dinyatakan valid, hal ini berdasarkan keputusan bahwa apabila $r$ hitung lebih besar daripada $r$ tabel, maka kuesioner tersebut valid, di dalam uji validitas variabel ini, $r$ tabel nya adalah 0.183 dan semua $r$ hitung yang ada di data melebihi angka tersebut.

Dari hasil penelitian, nilai cronbach alpha yang dimiliki oleh ketiga variabel di atas memiliki nilai di atas standar cronbach alpha suatu kuesioner yaitu (0.6), maka data bisa digunakan untuk penelitian.

\section{Hasil Uji Normalitas}

Dalam penelitian ini, hasil uji normalitasnya yaitu 0.511, yang di mana angka tersebut sudah berada di atas 0.5 , dengan kata lain, data yang dikumpulkan oleh kuesioner pada penelitian kali ini sudah lulus uji normalitas $(0.511(\mathrm{SIG})>0.5)$.

\section{Hasil Uji Heteroskedastisitas}

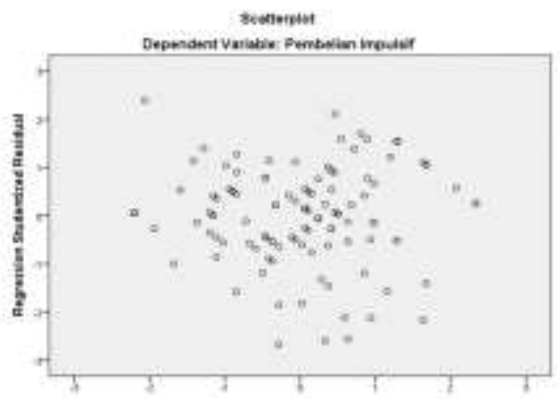

Sumber: Data diolah (2020)

\section{Gambar 2. HASIL UJI HETEROSKEDASTISITAS}

Gambar 2 memerlihatkan bahwa tidak adanya bentuk khusus ataupun titik berkumpul yang ditimbulkan oleh titik titik di gambar. Semua titik yang mengisi bidang tersebut menyebar. Artinya, data yang digunakan dalam penelitian kali ini sudah lulus uji heteroskedastisitas.

\section{Hasil Uji Multikolinearitas}

Uji asumsi klasik yang selanjutnya adalah uji multikolinearitas yang bertujuan untuk mengetahui ada atau tidaknya hubungan yang linier antara variabel bebas dalam model regresi. Dalam uji multikolinearitas, nilai yang diperhatikan adalah nilai Tolerance dan VIF. Apabila nilai Tolerance 
Wulandari et al., Pengaruh Electronic Word of Mouth dan Potongan Harga terhadap Pembelian Impulsif Suatu Produk Skincare

$<1.000$ dan atau nilai VIF $>10$, tidak terdapat multikolinearitas. Dengan berpatokan data yang ditampilkan pada lampiran 1, nilai Tolerance sebesar .761 dan VIF sebesar 1.314. Maka dari itu, tidak terdapat multikolinearitas dalam penelitian ini.

\section{Hasil Uji Autokorelasi}

Uji asumsi klasik selanjutnya adalah uji autokorelasi. Dalam menguji autokorelasi di dalam penelitian ini menggunakan uji durbin-watson. Dalam penelitian ini menunjukkan bahwa nilai d dari data yang ada menunjukkan angka sebesar 2.013, selanjutnya melihat nilai dU dengan jenis data $\mathrm{n} 100$ dan $\mathrm{k} 2$ adalah 1.715. Dengan demikian, dapat nilai d yang dimiliki data penelitian > dari nilai dU (2.013 > 1.715) Maka tidak terdapat masalah autokorelasi dalam penelitian ini.

Tabel 1.

ANALISIS UJI AUTOKORELASI

\begin{tabular}{lrrrrr}
\hline Model & $\boldsymbol{R}$ & $\boldsymbol{R}$ Square & $\begin{array}{c}\text { Adjusted } \boldsymbol{R} \\
\text { Square }\end{array}$ & $\begin{array}{c}\text { Std. Error of the } \\
\text { Estimate }\end{array}$ & Durbin-Watson \\
\hline 1 & $.771^{\mathrm{a}}$ & .594 & .587 & 2.485 & 2.013 \\
\hline
\end{tabular}

Sumber: Data diolah (2020)

Hasil Uji Hipotesis

Tabel 2.

HASIL UJI ANOVA

\begin{tabular}{llrrrrr}
\hline Model & & \multicolumn{1}{c}{ Sum of } & & & & \\
& & Squares & Df & Mean Square & \multicolumn{1}{c}{ F } & \multicolumn{1}{c}{ Sig. } \\
\hline 1 & Regression & 1012.281 & 2 & 506.140 & 81.937 & $.000^{\mathrm{b}}$ \\
& Residual & 691.841 & 112 & 6.177 & & \\
& Total & 1704.122 & 114 & & & \\
\hline
\end{tabular}

Sumber: Data diolah (2020)

Tabel 2, nilai $\mathrm{F}$ tabel dalam penelitian ini adalah 3.08. Sedangkan, f hitung yaitu 81.397. Nilai signifikansi sebesar $.000<0.05$. Artinya, ada pengaruh simultan variabel X1 $(e W O M)$ dan variabel X2 (potongan harga) terhadap variabel Y (pembelian impulsif).

Tabel 3.

HASIL UJI HIPOTESIS SECARA PARSIAL

\begin{tabular}{|c|c|c|c|c|c|c|}
\hline \multirow[b]{2}{*}{ Model } & & \multicolumn{2}{|c|}{$\begin{array}{c}\text { Unstandardized } \\
\text { Coefficients }\end{array}$} & \multirow{2}{*}{$\begin{array}{c}\text { Standardized } \\
\text { Coefficients } \\
\text { Beta }\end{array}$} & \multirow[b]{2}{*}{$t$} & \multirow[b]{2}{*}{ Sig. } \\
\hline & & B & Std. Error & & & \\
\hline \multirow[t]{3}{*}{1} & (Constant) & .596 & 2.145 & & .278 & .782 \\
\hline & eWOM & .391 & .071 & .381 & 5.523 & .000 \\
\hline & Potongan Harga & .518 & .070 & .509 & 7.376 & .000 \\
\hline
\end{tabular}

Sumber: Data diolah (2020)

Berdasarkan tabel 3, nilai $\mathrm{t}$ hitung (5.523) > t tabel (1.658) dan nilai sig $(.000)<0.05$, maka $\mathrm{H} 2$, adanya pengaruh parsial yang muncul oleh variabel X1 (eWOM) terhadap variabel Y (pembelian impulsif), dapat dibuktikan dalam penelitian ini. $t$ hitung (7.376.) $>\mathrm{t}$ tabel (1.658) dan nilai sig (.000) $<0.05$, maka H3 adanya pengaruh parsial yang muncul oleh variabel X2 (potongan harga) terhadap variabel Y (pembelian impulsif), dapat dibuktikan dalam penelitian ini.

\section{Pengaruh eWOM dan Potongan Harga terhadap Pembelian Impulsif}

Penelitian ini berhasil membuktikan H1. Maka, penelitian ini memiliki kesesuaian dengan penelitian yang sudah dilaksanakan oleh Setiawan \& Putri (2020) yang menunjukkan bahwa kedua variabel yaitu eWOM dan potongan harga dapat memberikan pengaruh yang positif kepada proses pembelian 
suatu produk, namun tetap ada variabel lain yang memberikan pengaruh pula pada proses terjadinya pembelian impulsif terhadap suatu produk. Implikasi praktis penelitian ini adalah perusahaan dapat mengolaborasikan kedua variabel eWOM dan potongan harga supaya dapat terus meningkatkan proses pembelian impulsif terhadap produknya.

\section{Pengaruh eWOM terhadap Pembelian Impulsif}

Dimensi yang mewakili variabel eWOM, yang terdiri dari pesan, sumber, dan bagaimana respon penerima, dapat dilihat bahwa dimensi yang memiliki pengaruh paling besar adalah dimensi pesan. Dimensi yang paling sedikit memberikan pengaruh adalah dimensi respon penerima eWOM. Penelitian ini memiliki hasil sama dengan penelitian terdahulu oleh Sugianto (2017) menekankan dan menunjukkan bahwa ada pengaruh eWOM terhadap citra dan proses pembelian impulsif suatu produk. Implikasi penelitian ini terhadap kondisi pemasaran perusahaan yaitu manajer harus memberikan perhatian khusus kepada segala sesuatu yang dapat dilihat para konsumen, sehingga memberikan kesan dan penilaian positif terhadap produk yang bersangkutan dan dapat menciptakan eWOM yang baik dan efektif,

\section{Pengaruh Potongan Harga Terhadap Pembelian Impulsif}

Dimensi yang mewakili variabel potongan harga, yang terdiri dari besaran, masa, dan jenis produk yang mendapat potongan harga, dapat dilihat bahwa dimensi yang memiliki pengaruh paling besar adalah dimensi besaran potongan harga. Dimensi yang paling sedikit memberikan pengaruh adalah dimensi jenis produk yang mendapat potongan harga. Penelitian ini mendukung hasil penelitian terdahulu oleh Kusnanto et al. (2020) menekankan dan menunjukkan bahwa ada pengaruh dari potongan harga terhadap citra dan proses pembelian impulsif suatu produk. Perusahaan harus jeli dalam menetapkan potongan harga terhadap suatu produk agar dapat efektif. Berapa besaran potongan harga dari produk tertentu, yang menarik minat beli konsumen.

\section{KESIMPULAN}

Hasil penelitian menunjukkan bahwa kedua variabel yaitu eWOM dan potongan harga berpengaruh secara positif terhadap pembelian impulsif. Secara partial eWOM juga berpengaruh positif terhadap pembelian impulif, begitu juga dengan potongan harga berpengaruh positif terhadap pembelian impulsiff. Hasil penelitian dapat memberikan implikasi bahwa eWOM dan potongan harga merupakan teknik pemasaran yang penting untuk memengaruhi konsumen melakukan pembelian. Hasil penelitian ini mendukung penelitian-penelitian sebelumnya bahwa eWOM dan potongan harga berperan penting dalam memengaruhi keputusan konsumen untuk melakukan pembelian. Keterbatasan penelitian ini terletak pada jumlah responden yang terbatas yaitu 162 responden, dan proses pengambilan data mengenai informasi yang diberikan responden melalui online, sehingga faktor kejujuran dalam pengisian tidak bisa diamati. Penelitian ini bisa dijadikan bahan referensi untuk penelitian selanjutnya dalam memerdalam penelitian dengan menambahkan variabel lain anteseden dari pembelian impulsif.

\section{DAFTAR PUSTAKA}

Agatha, C., Tumbel, A., Soepeno, D. (2019). Pengaruh Brand Image dan Electronic Word of mouth Terhadap Minat Beli Konsumen Oriflame di kota Manado, Jurnal Riset Ekonomi, Manajemen, Bisnis dan Akuntansi, 7(1).

Baskara, I. B. (2015). Pengaruh Potongan Harga atau Discount kepada Keputusan Pembelian Tidak Terencana (Impulse Buying), Manajemen Bisnis, 5(2).

Dalihade, M.P., Massie, J. D.D., Tielung, M. V. J. (2017). Pengaruh Potongan Harga dan Store Atmosphere Tterhadap Impulse Buying pada Matahari Departement Store Mega Mall Manado, Jurnal Riset Ekonomi, Manajemen, Bisnis dan Akuntansi. 1(11). 
Wulandari et al., Pengaruh Electronic Word of Mouth dan Potongan Harga terhadap Pembelian Impulsif Suatu Produk Skincare

Dewi I. K.,\& Kusumawati, A. (2018). Pengaruh Diskon terhadap Keputusan Pembelian dan Kepuasan Pelanggan Bisnis Online (Survei pada Mahasiswa Fakultas Ilmu Administrasi Universitas Brawijaya Angkatan 2013/2014 Konsumen Traveloka), Jurnal Administrasi Bisnis, 56(1).

Ismagilova, E., Dwivedi, Y.K., Slade, E., Williams, M. (2017). Electronic Word of mouth in the marketing context (A state of art analysis and future directions). Swansea: Springer.

Euromonitor.com.(2020). The Impact of Coronavirus on Beauty and Personal Care (https://www.euromonitor.com/the-impact-of-coronavirus-on-beauty-and-personal-care/report, diakses pada 1 Mei 2020)

Tjiptono, F. (2019). Strategi Pemasaran. Yogyakarta: Andi.

Hardani. (2020). Metode Penelitian (Kuantitatif dan Kualitatf). Yogyakarta: CV PUSTAKA ILMU.

Jannah, N. R.,\& Suswardji, E. (2021). Pengaruh Citra Merek dan Electronic Word of mouth terhadap minat beli produk kecantikan wardah, COSTING : Journal of Economic, Business and Accounting, 4(2).

Kemp, S. (2019). Digital 2020: 3.8 Billion People Use Social Media. New York. (https://wearesocial.com/blog/2020/01/digital-2020-3-8-billion-people-use-social-media.

Diakses pada tanggal 20 Juni 2020)

Kusnanto, D., Haq, A.A.F., Fahmi, I.S., (2020) Pengaruh potongan harga terhadap pembelian impulsif pada pengguna aplikasi Grabfood, Jurnal Manajemen, 12(1).

Philip Kotler, K. L. (2015). Marketing Management Global Edition (15th). London: Pearson.

Soco.id (2018). Mediheal. https://review.soco.id/brand/235/mediheal. (Diakses pada 23 Desember 2020).

Rosario, A.B, Sotgiu, F., De Valck, K., \& Bijmolt, T. H. A. (2016). The Effect of Electronic Word of Mouth on Sales: A Meta-Analytic Review of Platform, Product, and Metric Factors. Journal of Marketing Research, 53(3), 297-318. doi:10.1509/jmr.14.0380

Rook, D. W. (1987). The Buying Impulse. Journal of Consumer Research, 14(2), 189.

Setiawan, A., Putri, Y.S.(2020). The Effect of Discounts, Electronic Word of Mouth (Ewom), And Price Towards Interest In Buying In E-Commerce, Journal of Islamic Economic Scholar, 1(1). $125-143$

Sandu Suyoto, M. S. (2015). Dasar Metodologi Penelitian. Karanganyar-Klodangan: Literasi Media Publishing.

Sugiyono, P. D. (2013). Metode Penelitian Kuantitatif, Kualitatif Dan R\&d. Bandung: Alfabeta

Sugianto, Y. M. N. (2017). Pengaruh Website Quality, Electronic Word-of-Mouth, dan Sales Promotion terhadap Impulse Buying Pada Zalora, Jurnal Strategi Pemasaran, 3(2).

Weisfeld-Spolter, S., Sussan, F., \& Gould, S. (2014). An Integrative Approach to eWOM and Marketing Communications. Corporate Communications: An International Journal, 19(3), 260-274.

Yulianton, H., Sutanto,F.A., Hadiono, K. (2017). Analisa Electronic Word of Mouth (E-Wom) pada Media Sosial Twitter. DINAMIK. 22(1), 11-22 
Jurnal Ilmu Manajemen Volume 9 Nomor 3

\section{Lampiran 1. ANALISIS UJI MULTIKOLINEARITAS}

\begin{tabular}{|c|c|c|c|c|c|c|c|c|}
\hline \multirow{2}{*}{\multicolumn{2}{|c|}{ Model }} & \multicolumn{2}{|c|}{$\begin{array}{c}\text { Unstandardized } \\
\text { Coefficients }\end{array}$} & \multirow{2}{*}{$\begin{array}{c}\text { Standardized } \\
\text { Coefficients } \\
\text { Beta } \\
\end{array}$} & \multirow[b]{2}{*}{$t$} & \multirow[b]{2}{*}{ Sig. } & \multirow{2}{*}{\multicolumn{2}{|c|}{$\begin{array}{c}\text { Collinearity } \\
\text { Statistics }\end{array}$}} \\
\hline & & $\boldsymbol{B}$ & Std. Error & & & & & \\
\hline \multirow[t]{3}{*}{1} & (Constant) & .596 & 2.145 & & .278 & .782 & & \\
\hline & eWOM & .391 & .071 & .381 & 5.523 & .000 & .761 & 1.314 \\
\hline & Potongan Harga & .518 & .070 & .509 & 7.376 & .000 & .761 & 1.314 \\
\hline
\end{tabular}

Sumber: Data diolah (2020) 